\title{
The Global Health Security Agenda in an Age of Biosecurity
}

Lawrence O. Gostin

Georgetown University Law Center, gostin@law.georgetown.edu

Alexandra Phelan

Georgetown University Law Center, alp81@georgetown.edu

This paper can be downloaded free of charge from:

https://scholarship.law.georgetown.edu/facpub/1356

http://ssrn.com/abstract=2461850

312 JAMA 27-28 (2014)

This open-access article is brought to you by the Georgetown Law Library. Posted with permission of the author. Follow this and additional works at: https://scholarship.law.georgetown.edu/facpub

Part of the Health Law and Policy Commons, International Law Commons, International Public Health Commons, and the Public Policy Commons 


\section{The Global Health Security Agenda in an Age of Biosecurity}

Lawrence O. Gostin, JD

O'Neill Institute for National and Global Health Law, Georgetown University Law Center, Washington, DC, and World Health Organization Collaborating Center on Public Health Law and Human Rights, Washington, DC.

\section{Alexandra Phelan,} LLM, BBiomedSc (Hons)

O'Neill Institute for National and Globa Health Law, Georgetown University Law Center, Washington, DC

\section{Corresponding} Author: Lawrence O. Gostin, JD, Georgetown University Law Center, O'Neill Institute for National and Global Health Law, 600 New Jersey Ave NW, Washington, DC 20001 (gostin@law .georgetown.edu).
In May 2009, President Obama launched the Global Health Initiative with ambitious goals of reforming foreign assistance, expanding programs, and coordinating agencies. Despite progress, these goals have been only partially achieved. Yet 5 years later, on February 13, 2014, the White House launched another bold initiative-the Global Health Security Agenda (GHS Agenda), a US-led diplomatic collaboration with 30 countries, international organizations, nongovernmental organizations, and public/private entities. The GHS Agenda aims to "accelerate progress toward a world safe and secure from infectious disease threats."1 Does the GHS Agenda signal the end of the Global Health Initiative, and is the policy shift toward securitization a positive step for global health?

\section{The GHS Agenda}

The intertwining of global health and security follows a line of international agreements. The 2003 global outbreak of severe acute respiratory syndrome energized the international community, leading to the revised International Health Regulations (IHR) in 2005, which set global standards for surveillance and response to pandemic threats. Adopting an "all-hazards" approach, the revision covered "public health emergencies of international concern" rather than the 3 diseases covered in the old regulations (cholera, yellow fever, and bubonic plague). The IHR established systematic approaches to international cooperation, surveillance, risk assessment, and response capacities, improving the global response to the 2009 influenza A(H1N1) outbreak. However, by its implementation deadline in mid-2012, only 42 (22\%) of 194 World Health Organization (WHO) member states had reported fully developed core competencies, including legislation, surveillance, response, and preparedness capacities. ${ }^{2}$ With the final implementation deadline looming in June 2016, the White House sought to forge a security framework in the GHS Agenda. ${ }^{3}$

\section{Enhanced Prevention}

The GHS Agenda's "enhanced prevention" has 4 priorities: (1) antimicrobial resistance, prioritizing the implementation of at least 1 reference laboratory per target country capable of identifying priority antimicrobial threats and reporting to the IHR focal point network; (2) biosecurity and biosafety, with national systems that can identify, secure, and monitor dangerous pathogens, particularly "gain of function" and "dual-use" research; (3) reduced spillover of zoonotic diseases into human populations, such as the March 2014 Guinean Ebola outbreak; and (4) broadened immunization coverage, with at least $90 \%$ of a target country's 1-yearolds vaccinated.

\section{Robust Detection}

The GHS Agenda facilitates robust detection through real-time biosurveillance and modern diagnostics to reliably conduct 5 of 10 core diagnostic tests within a health care setting or laboratory. Laboratory capacity should include IHR-notifiable diseases (eg, novel influenza subtypes), as well as WHO's leading causes of death in lowincome countries. The GHS Agenda will support the establishment of 1 trained field epidemiologist per 200000 population in target countries through financial and technical assistance, depending on national economic status.

\section{Effective Response}

The GHS Agenda aims for Emergency Operations Centers to activate a coordinated response within 2 hours, including rapid response units-multidisciplinary teams deployed to a public health emergency to investigate, evaluate patients, collect samples, oversee containment (eg, isolation or quarantine), and communicate among health authorities. In a suspected or confirmed biological attack, response teams would collaborate with law enforcement.

\section{Setting Norms Without Adequate Funding} The GHS Agenda signals a major advance in global health security. Whereas the IHR is framed in broad terms, the agenda specifies action steps, such as early detection, laboratory capacity, and rapid response-with defined benchmarks. While WHO has been unable to negotiate a multilateral agreement on antimicrobial resistance (perhaps the world's leading health threat) or on research and development, the GHS Agenda prioritizes cross-border cooperation on virus sharing and research. As a US-led consortium, the GHS Agenda brings together international organizations, states, nongovernmental organizations, and public/private partnerships-an inclusive approach, often politically challenging for United Nations agencies.

The obstacles, however, to effective implementation are formidable. The United States lacks legitimacy to set global norms and guide state conformance. Without a legal mandate to spearhead global preparedness, sovereign states could, over time, fail to comply. With a presidential election in 2016, the next incumbent could pivot in a different direction. The GHS Agenda's coordinating function is vital, but the administration failed to secure seamless coordination even across federal agencies. Will it be possible to do so across divergent states?

Indonesia's refusal to share influenza A(H5N1) samples in 2006 destabilized the international community, resulting in WHO's adoption of the Pandemic Influ- 
enza Preparedness (PIP) Framework in 2011 to facilitate equitable sharing of samples and vaccines. The PIP Framework, however, does not expressly cover genetic sequencing data that are increasingly used to transfer knowledge, and it does not cover noninfluenza materials, such as Middle East respiratory syndrome. The agenda cannot rectify these deficiencies, which ultimately requires WHO to clarify the IHR and PIP Framework.

The signal failure of the IHR was the inability to persuade highincome states to help build core capacities in poorer countries. A US-led consortium could succeed where WHO failed. Yet, President Obama's 2015 budget proposal allocates only $\$ 45$ million to Centers for Disease Control and Prevention GHS activities, ${ }^{4} 82$ which will not go far when shared among the initial 10 target countries, so far identified only as low- and middle-income countries with a clear need and willingness to make rapid progress. Even if funding were ample, Congress is unlikely to enact the president's budget, so even sparse funding is not ensured.

Status of the Global Health Initiative Historically, the Oval Office has launched vital global health programs, including the President's Emergency Plan for AIDS Relief (PEPFAR) in 2003 and the President's Malaria Initiative in 2005. Initially intended to last only 5 years, both programs were extended by Congress. The White House created the Global Health Initiative to coordinate implementation across various departments. Without fanfare, however, the Global Health Initiative offices were closed in mid-2012.

The policy directions of the Global Health Initiative and GHS Agenda also appear to be quite different, with the former primarily intended to solidify major aid programs for endemic diseases such as AIDS, tuberculosis, and malaria. The GHS Agenda focuses on rapidly emerging infections, but the major share of US global health funding remains in PEPFAR and the President's Malaria Initiative. Notably, the president's budget proposes a $4 \%$ overall reduction in global health funding, ${ }^{5}$ and fiscal conservatives could seek further reductions.

\section{Securitization of Global Health}

The GHS Agenda stresses securitization, with important implications. Biosecurity is high on the national and international agenda, especially with currently circulating novel influenza A(H7N9) and Middle East respiratory syndrome. Still, the primary disease burdens worldwide (and the predominant concern of lower-income countries) continue to be endemic infectious diseases, noncommunicable diseases, injuries, and mental health. For most of the world, security primarily means building health systems to meet everyday needs. Historically, biosecurity has been more a concern of wealthier countries, beginning as far back as the first European Sanitary Conference in $1850 .^{6}$

Securitization has become a common thread in foreign aid and development in the post-9/11 world. Security has the power to motivate high-income countries to invest and take decisive action. Just as the AIDS pandemic transformed global health assistance, biosecurity has the potential to ensure preparedness-a mobilization that may not have occurred if endemic disease was the sole political consideration. Reframing global health through the prism of security could be transformative.

The GHS Agenda merits support, not only to enhance security but also to build fundamental public health capacities in lowerincome countries. With a proposed budget allocation of only $\$ 45$ million, the GHS Agenda is a very small amount when compared with the $\$ 8.1$ billion proposed for global health programs such as PEPFAR and the President's Malaria Initiative. Consequently, the GHS Agenda will require considerable presidential leadership and strong buy-in from Congress, together with stakeholders. However, if successful, the United States, a historical global health leader, could succeed where international organizations have not always been able to, building a safer and healthier world for all of humanity.

\section{ARTICLE INFORMATION}

Conflict of Interest Disclosures: The authors have completed and submitted the ICMJE Form for Disclosure of Potential Conflicts of Interest and none were reported

REFERENCES

1. US Department of Health and Human Services. Global Health Security Agenda: Toward a World Safe \& Secure From Infectious Disease Threats. February 13 2014. http://www.globalhealth.gov/global-health
-topics/global-health-security/GHS\%20Agenda .pdf. Accessed April 5, 2014

2. Kerry J, Sebelius K, Monaco L. Why global health security is a national priority. CNN. February 12 , 2014. http://www.cnn.com/2014/02/12/opinion /kerry-sebelius-health-security/index.html. Accessed April 5, 2014

3. Inglesby T, Fischer JE. Moving ahead on the global health security agenda. Biosecur Bioterror. 2014;12(2):63-65.

4. US Office of Management and Budget. Fiscal Year 2015, Budget of the US Government. March 4,
2014. http://www.whitehouse.gov/sites/default/files /omb/budget/fy2015/assets/budget.pdf. Accessed April 5, 2014

5. Wexler A, Kates J. The US Global Health Budget: Analysis of the Fiscal Year 2015 Budget Request. March 20, 2014. http://kff.org/global-health-policy /issue-brief/the-u-s-global-health-budget -analysis-of-the-fiscal-year-2015-budget-request/. Accessed April 5, 2014

6. Gostin LO. Global Health Law. Cambridge, MA Harvard University Press; 2014 